\title{
Die Christus-himne in Filippense: soteriologies of eties?
}

\section{Floor}

Emeritus: Departement Ou \& Nuwe

Testament

Potchefstroomse Universiteit vir $\mathrm{CHO}$

POTCHEFSTROOM

E-pos: Ifloor@mweb.co.za
F.P. Viljoen

Skool vir Bybelwetenskapppe

en Bybeltale

Potchefstroomse Universiteit vir $\mathrm{CHO}$ POTCHEFSTROOM

E-pos: sbbfpv@puknet.puk.ac.za

\begin{abstract}
The Christ hymn in Philippians: Soteriological or ethical?

The Christ hymn (Philippians 2:6-11) presents Jesus as the supreme example of humble, self-sacrificing, self-denying, self-giving service. The apostle Paul urges the Philippians to practise such conduct in their relation to one another. Hence, although this hymn is unquestionably an ethical poem, it may also be considered as soteriological in character. This hymn was composed for christological and soteriological reasons, but Paul's motive is in the first place not to give an instruction in doctrine, but to reinforce instruction in Christian living. The hymn, therefore, presents Christ as the ultimate model for moral action. Paul uses Christ's life and death as an example for Christians to follow.
\end{abstract}

\section{Probleemstelling}

In die literatuur bestaan twee interpretasiemoontlikhede vir die verklaring van die Christus-himne in Filippense 2:6-11. Volgens sommige navorsers (byvoorbeeld Schenk, 1984:129) moet die himne eties verklaar word. Volgens ander (bv. Gnilka, 1968:175; Martin, 1983:135 en Snyman, 1989:52) moet dit soteriologies verklaar word. Hierdie twee interpretasiemoontlikhede word soms lynreg teenoor mekaar gestel. In hierdie artikel word ondersoek in hoeverre hierdie twee interpretasiemoontlikhede mekaar uitsluit en of hulle nie tog met mekaar versoenbaar is nie. 
As vertrekpunt vir die ondersoek word eers gevra na die oorsprong van die lied. Die moontlikheid word ondersoek of 'n antwoord op die probleem gevind kan word uit dit wat aanleiding gegee het tot die invoeging van die himne in die Filippense-brief, die waarskynlike oorsprong daarvan en die outeur van die himne. Voorts word die soteriologiese en etiese verklarings in die lig van die struktuur en konteks van die himne beoordeel.

Die fokus op hierdie probleem veroorsaak dat nie op allerlei vrae met betrekking tot die verskillende onderdele van die lied ingegaan kan word nie. Net waar ' $n$ bepaalde frase uit die himne vir die probleemstelling relevant is, sal aandag daaraan gegee word.

\section{Die aanleiding tot die himne}

Toe Bornhäuser in 1938 sy bekende Jesus Imperator Mundi, 'n vergelykende studie oor Filippense 3:17-21 en 2:5-11 gepubliseer het, het hy die opmerking gemaak dat wie begin om alles wat oor Filippense 2:5-11 geskryf is te versamel, in ' $n$ kort tyd in die besit sal wees van 'n hele biblioteek (Bornhäuser, 1938:124). Oor die afgelope 63 jaar het daar minstens nog 'n omvangryke biblioteek bygekom.

Tog lyk die saak met betrekking tot die Filippense-himne met die eerste oogopslag baie eenvoudig. Paulus spoor sy lesers aan tot 'n bepaalde

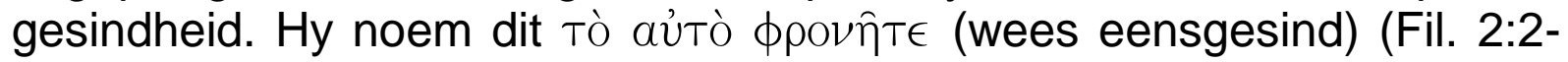
3). Na sy aansporing tot hierdie gesindheid, illustreer die apostel dit met 'n voorbeeld. In 2:5 omskryf hy dan hierdie gesindheid en noem dit "dieselfde gesindheid moet in julle wees wat daar ook in Christus Jesus

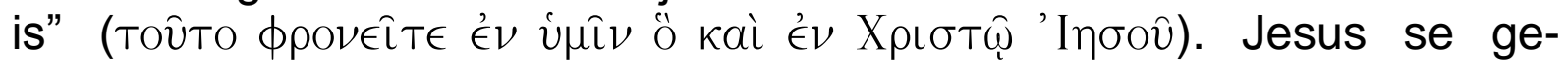
sindheid word as die groot voorbeeld aan die gelowiges voorgehou. Die eensgesindheid waartoe die apostel sy lesers aanmoedig, moet daarom 'n saak van die hart wees. Die gesindheid moet "in julle" ( $€ \nu$ v $\mu \hat{\imath} \nu)$ wees.

Dit is nie vreemd dat die skrywer van die brief aan die Filippense 'n direkte lyn van Christus na die gelowiges trek nie. Daar is in die Nuwe Testament baie verwysings dat die lewe wat Jesus op aarde geleef het, as voorbeeld vir sy volgelinge dien (vgl. Matt. 11:29; Joh. 13:12-17; 13:34; 1 Kor. 11:1; 1 Tess. 1:6; 1 Pet. 2:21-23; 1 Joh. 2:6).

Wanneer Paulus Christus se gesindheid as 'n voorbeeld stel, doen hy dit in die vorm van 'n lied, die sogenaamde Christus-himne (Fil. 2:6-11). Hierdie verse vertoon 'n bepaalde struktuur. Of dit die struktuur van 'n lied is, word deur sommige navorsers betwyfel. Fee (1995:193) is byvoorbeeld oortuig dat hierdie gedeelte van die brief, hoe verhewe ook al geformuleer, nie die einskappe van 'n himne het nie, maar dat dit 
eerder 'n verhalende (narratiewe) aard het. Die meeste navorsers aanvaar egter wel, met oortuigende argumente, dat dit 'n lied is (vgl. onder andere Fitzmyer, 1968:247-253; Murphy-O'Conner, 1976:25-26; Robertson, 1917:123; Weiss, 1897:28 e.v.).

\section{Die oorsprong van die lied}

Vanaf die einde van die negentiende eeu het eksegete nie meer alleen aandag gegee aan die betekenis van hierdie "oud-Christelike himne" nie, maar hulle het ook die moontlike voor-Pauliniese agtergrond, die literêre vorm, die retoriek en die ritmiese aard van die lied bestudeer (vgl. Guthrie, 1970:539-540, Murphy-O'Connor, 1976:25-26 en Pelser, 1971: 260-280 wat 'n goeie oorsig van die die navorsing bied). Dit is blykbaar so dat Paulus hom by bestaande musiektradisies aangesluit het in sy gebruik van en verwysing na himnes in sy briewe (Viljoen, 2001:440).

Weiss (1897:28vv) was 'n baanbreker in bogenoemde navorsing oor die Filippense-himne. Robertson (1917:123), Moffat (1918:167) en Dibelius (1925:72) het hom hierin gevolg. Lohmeyer (1928:75) het navorsing oor die himne 'n nuwe koers gegee met sy oortuiging dat Filippense 2:6-11 'n voor-Pauliniese, Christologiese himne is met sterk Semitiese kenmerke.

Wat die literêre vorm betref, het baie navorsers opgemerk dat die lied voor-Paulinies moet wees (vgl. onder andere Sanders, 1963:90-111). Sommige van die belangrikste argumente is dat verskeie fomuleringe wat in die himne voorkom, nie elders in die corpus Paulinum gebruik word nie. Formuleringe waarna dikwels verwys word, is "die gestalte van

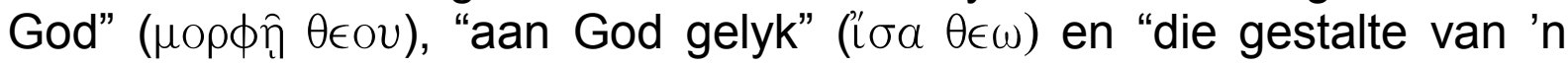

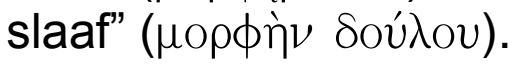

Oor die presiese oorsprong van die lied bestaan daar verskeie standpunte wat vervolgens net genoem word. ${ }^{1}$ Die lied in Filippense word onder andere gesien as:

- 'n Joods-Christelike produk (Cerfaux, 1946:93-95; Lohmeyer, 1930: 88).

- 'n Rekonstruksie van 'n Aramese himne (Fitzmyer,1993:251).

- Ook word gesê dat dié lied óf vanuit 'n Joods-Hellenistiese agtergrond ontstaan het (Bonnard, 1950:42; Cullmann, 1957:179; Dunn, 1980: 117 ), óf 'n Grieks-Romeinse agtergrond het (Hurtado, 1984:744), óf

1 Sanders (1963:90-111) bied 'n oorsig van die bestaande voorstelle oor die godsdienstige agtergrond van die lied. 
deel vorm van die Joods-Hellenistiese wysheidsliteratuur (Georgi, 1964:261).

- Verder word beweer dat dit 'n bestryding van die gnostisisme verteenwoordig (Käsemann, 1960:89; Maartin 1983:132); of dat dit 'n produk is wat die Filippense self ontwerp het op grond van die Christologie en die vroomheid wat hulle van Paulus geleer het (Schenk, 1984:131).

- 'n Enkele eksegeet, Barnikol (1932:68), oordeel selfs dat die lied postPaulinies is.

\section{Teorieë oor die outeurskap}

In aansluiting by die vraag oor die oorsprong van die himne ontstaan die vraag of Paulus wel in staat sou wees om self so 'n himne te komponeer. Indien Romeine 8:31-39; 11:33-36 en 1 Korintiërs 13 as Paulinies aanvaar sou word, blyk dit inderdaad so. ${ }^{2}$ Furness (1958) beredeneer met 'n groot aantal argumente dat hierdie lied nie 'n voor-Pauliniese, oud-Christelike himne is nie. Hy pleit daarom ten gunste van die Pauliniese outeurskap. Gundri (1994:284) sluit hom met sy linguistiese analise van die himne by die standpunt van Furness aan.

Teorië oor die nie-Pauliniese outeurskap van die lied het vanselfsprekend die eksegese van die himne beïnvloed. Veral die teologiese gehalte van die lied het onder skoot gekom. Twee argumente is daarby ter sprake.

- Die lied sou 'n ander soteriologie as dié van Paulus hê. Daar ontbreek byvoorbeeld 'n duidelike heenwysing na die kruis van Christus. Sommige Skrifverklaarders (bv. Käsemann, 1960:104 en Lohmeyer, 1961:152) is van mening dat die gedagte van die kruisdood van

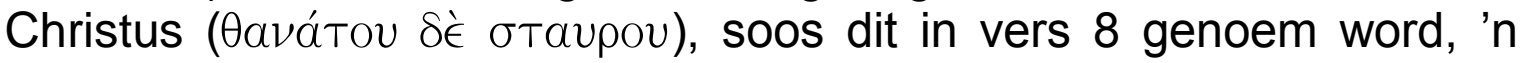
steurende element is wat die ritme van die lied verbreek. ${ }^{3}$ Hulle is van mening dat Paulus die lied oorgeneem het en toe sy eie verlossingsleer daarby ingebou het. Die dood van Christus aan die kruis sou 'n Pauliniese glos wees.

- As tweede argument vir die nie-Pauliniese oorsprong van die lied voer Fee (1995:192) en Vögtle (1963:203) aan dat die lied oorspronklik

2 Furness (1958:241) beredeneer die waarskynlikheid dat Paulus ook die outeur van hierdie liedere was. Die apostel sou volgens hom daarom ook die digterlike aanleg gehad het om self die Filippense-himne te komponeer.

3 Snyman (1989:44) het in sy analise van die lied sonder behoorlike tekskritiese begronding die gedeelte oor die kruis weggelaat. 
eties van aard was. Paulus, of wie ook al, sou gegewens uit die heilsgeskiedenis ingevoeg het om die lied meer soteriologies te maak.

Dit is juis oor die soteriologie waaroor baie eksegete probleme ondervind by hulle interpretasie van hierdie himne.

\section{Christus as voorbeeld bevraagteken}

Die belangrikste punt op Paulus se agenda met die Filippense was die bestryding van onenigheid (vgl. Floor, 1998:83). Hulle moes leer om eensgesind te wees, hulleself te verloën en die selfverloëning en nederigheid van Christus as voorbeeld te aanvaar. Die gesindheid van Christus word aan die lesers as dié groot voorbeeld voorgehou.

Kennedy (1984:89) het die vermoede uitgespreek dat die inhoud van die lied teruggaan op 'n evangelietradisie wat die apostel Paulus met die apostel Johannes sou deel. Die berig van die voetwassing in Johannes 13:3-17 vertoon inhoudelik 'n duidelike ooreenkoms met die selfvernedering van die Seun in Filippense 2:6-11.

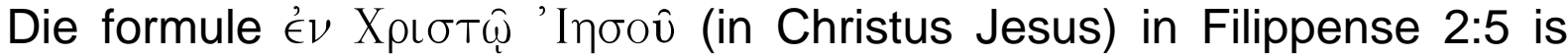
deur Schenk (1984:129) as vertrekpunt geneem om vas te stel of die skrywer deur Jesus se gedrag 'n voorbeeld vir die gelowiges wou stel. Die navolging van Christus is volgens Schenk dan nie met hierdie formule bedoel nie, maar die geloofsverbondenheid met Christus. Hy motiveer sy stelling met sy oortuiging dat die teks (Filippense 2:6-11) nie deur Paulus geskryf is nie, maar deur die Filippense self ontwerp is. Hulle het dit gedoen op die basis van die Christologie en vroomheid wat hulle van Paulus geleer het. Die Filippense sou as Hellenisties-Romeinse burgers hierdie teks gebruik het as propagandamateriaal by hulle geloofsgetuienis teenoor die nie-Christene in hulle omgewing. Paulus sou hierdie ontwerp dankbaar in sy brief opgeneem het. Daarom oordeel Schenk dat die himne nie verduidelik dat die gelowiges Jesus moet navolg nie. Slegs hulle geloofsband met Jesus word daardeur beskryf.

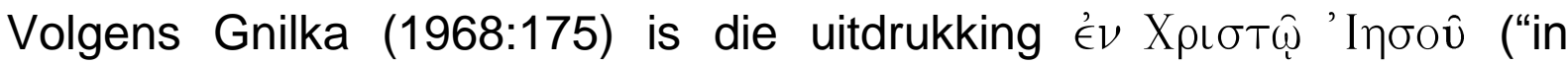
Christus Jesus") soteriologies bedoel. Dit het betrekking op die verlossing van die sondaar.

Dié uitdrukkig sou ook ekklesiologies verstaan kon word volgens Bonnard (1950:103) en Martin (1983:132). Dit sou die Christen se verhouding tot die kerk beskryf. Strecker (1964:74) besef dat met 'n ekklesiologiese verklaring die lied uit sy konteks gelig word, omdat die "kerk" in die perikoop en selfs in die hele brief nie 'n rol speel nie. Daarom pleit hy vir 'n Christologies-etiese verklaring. 
Martin (1983:135) het probleme met 'n etiese verklaring van die (oorspronklike) himne. Volgens hom kon die himne een betekenis in sy oorspronklike konteks gehad het, maar 'n ander betekenis in die Filippensebrief. By die interpretasie van die himne in sy Filippensekonteks sou 'n mens vrae oor die oorspronklike doel van die lied moes opskort en vra na die betekenis wat Paulus daaraan gegee het in Filippense 2:6-11. Vanuit strukturele en stilisties oorwegings (van die himne buite die Filippense-konteks) beredeneer hy dat Christus se vernedering onmoontlik as 'n voorbeeld vir sy volgelinge gestel kan word. Vir hom is van belang die kosmologiese rol wat in so 'n tradisionele lied aan Christus toegeken word.

Ook Snyman (1989:52) ag Christus se selfvernedering so uniek dat Hy nie as ' $n$ voorbeeld vir nederigheid aan die Filippense voorgehou kan word nie. Hy volg Martin daarin na om 'n onderskeid te tref tussen die betekenis van die himne onderskeidelik binne en buite die Filippensebrief. Dit bly egter 'n vraag of sodanige onderskeid in die betekenismoontlikhede van die himne gemaak kan word.

\section{Die struktuur van die lied}

Daar was baie pogings om die struktuur van hierdie himne vas te stel (vgl. Fitzmyer, 1968:247-253 en Murphy-O'Connor, 1976:25-26 vir 'n oorsig van die navorsing). Uit die tallose voorstelle word twee uitgelig, omdat hulle die mees oortuigende is.

Die eerste is van Jeremias (1954:157) wat verse 6 tot 11 in drie strofes van elke vier reëls verdeel. Sy ontleding lui:

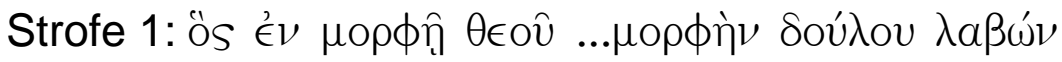

(Hy wat in die gestalte van God was ... die gestalte van 'n slaaf aangeneem)

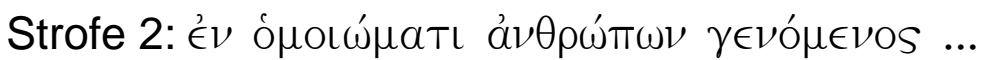

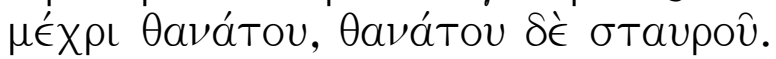

(En toe Hy as mens verskyn het ... tot die dood aan die kruis)

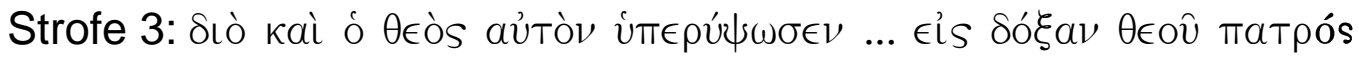
(Daarom het God Hom ook verhef ... tot eer van God die Vader).

Hunzinger (1970:149) gee 'n uitvoerige motivering vir hierdie indeling van Jeremias.

Die tweede voorstel kom van Martin (1983:147) wat die betrokke verse in ses stofes van elk twee reëls verdeel, dit wil sê: 
Strofe 1: vers 6

Strofe 2: vers 7

Strofe 3: vers 8

Strofe 4: vers 9

Strofe 5: vers 10

Strofe 6: vers 11

Vir albei voorstelle bestaan daar 'n goeie motivering. Die ses verse waaruit die lied bestaan, vertoon die struktuur van 'n ring- of spiraalkomposisie. Vers 6 begin met 'n verwysing na die goddelikheid van Christus en vers 11 eindig met Christus se verhoging as Here. Die eerste drie verse (6-8) handel oor Christus se vernedering en die laaste drie verse (9-11) oor Christus se verhoging. Daar vind 'n subjekverwisseling in die himne plaas. Die subjek van die eerste gedeelte van die lied (6-8) is Christus, hoewel Hy nie by name genoem word nie. In die tweede deel word die subjekte uitdruklik vermeld, naamlik God (9), elke knie (10) en elke tong (11).

Die grootste deel van die lied, twee derdes daarvan (die eerste twee strofes volgens Jeremias se verdeling), of vier strofes (volgens Martin) handel oor Christus se vernedering. Die dieptepunt van sy vernedering was sy gehoorsaamheid tot die dood. Die laaste deel van die himne (derde strofe volgens Jeremias) beskryf die gevolge van sy gehoorsaamheid. God het Hom uitermate verhoog, en alle mense moet die gekruisigde Jesus as Here dien.

In die volgende analise word die strofeverdeling van Jeremias gevolg en die fases van vernedering en verhoging aangetoon:

Fase van vernedering:

Strofe 1:

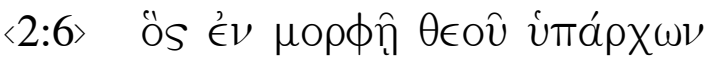

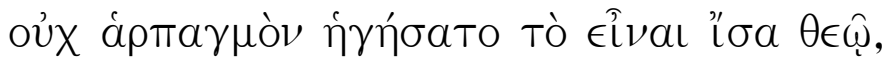

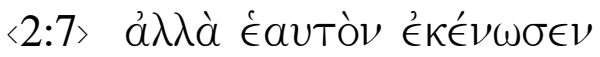

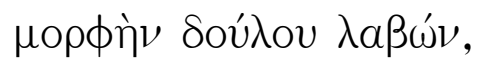

Strofe 2:

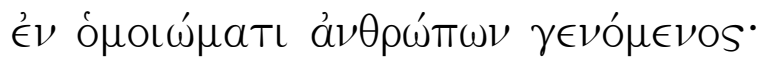

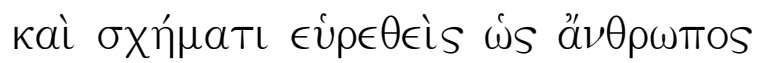

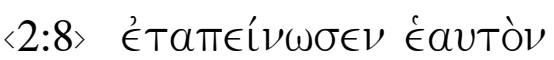

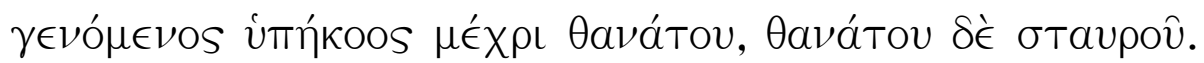


(Hy wat in die gestalte van God was, het sy bestaan op Godgelyke wyse nie beskou as iets waaraan Hy Hom moes vasklem nie, maar Hy het Homself verneder deur die gestalte van 'n slaaf aan te neem (en aan mense gelyk te word.)

En toe Hy as mens verskyn het, het Hy Homself verder verneder. Hy was gehoorsaam tot in die dood, ja, die dood aan die kruis) (1983 Afrikaanse vertaling.)

Fase van verhoging:

Strofe 3:

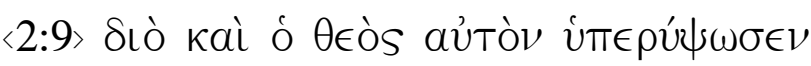

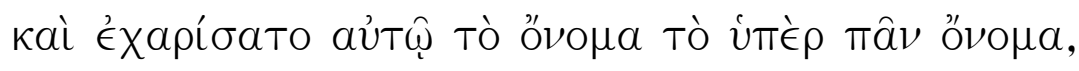

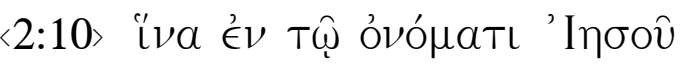

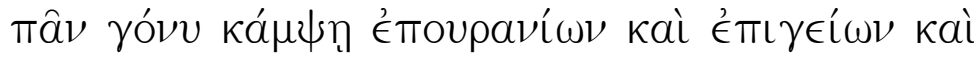

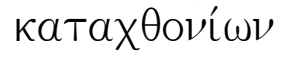

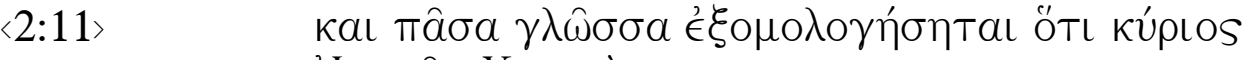

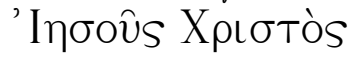

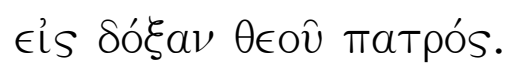

(Daarom het God Hom ook tot die hoogste eer verhef en Hom die Naam gegee wat bo elke naam is, sodat in die Naam van Jesus elkeen wat in die hemel en op die aarde en onder die aarde is, die knie sou buig, en elke tong sou erken: 'Jesus Christus is Here!' tot eer van God die Vader.)

\section{Interpretasie}

In die lied self is daar baie uitdrukkings wat by eksegete vrae opgeroep het, maar aangesien hierdie artikel fokus op die vraag na die teologiese en/of etiese interpretasie van die lied kan in hierdie artikel nie volle aandag aan hierdie aspek gegee word nie. Vergelyk Floor (1998:97-105) vir 'n uitvoerige bespreking van hierdie vraagstukke.

Hierdie artikel wil die lied op grond van sy teologiese en/of etiese gehalte weeg. Die vraag is of die lied eties of soteriologies van aard is.

Soos reeds aangetoon, roep 'n etiese interpretasie van die lied by baie eksegete ernstige besware op. Die lied is so sterk soteriologies en die kenosis (ontlediging) van Christus so uniek van aard dat dit onmoontlik as voorbeeld tot navolging kan dien. Dit is veral die kenosis-gedagte wat dit vir baie Skrifverklaarders (bv. Lohmeyer, 1928:75; Martin, 1983:135) onmoontlik maak om etiese implikasies daaruit te aanvaar. 


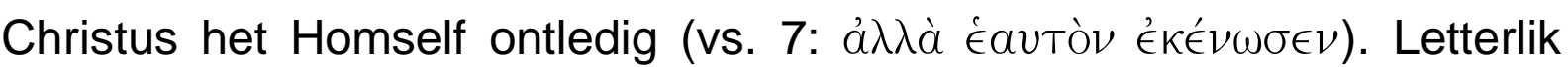
sou ons ook kon vertaal: "Hy het Homself leeg gemaak". Daar bestaan baie spekulasies oor die ontlediging van Christus. Waarvan het Christus Homself ontledig? Navorsers het onderskeidelik soos volg daarop geantwoord:

- Van sy glorie (Plummer, 1919:59);

- van die uitoefening van sy gesag (Hendriksen, 1962:108);

- van sy almag (Gore, 1891:103); en

- van sy "aan God gelyk wees” (Oepke, 1938:660).

Die werkwoord ontledig ( $\kappa \in \nu o ́ \omega)$ het by klassieke, Hellenistiese en patristiese skrywers die betekenis van: "jou geheel en al ter beskikking van ander mense stel" (Warren, 1912:462). Chrisostomos verwoord dit in 'n preek oor 1 Timoteüs (Homilie 13): "om te ontledig" beteken "om jou hele besit aan die armes te gee" (soos aangehaal deur Jones, 1918:24).

Hierdie selfvernedering van Christus is so uniek dat niemand Hom daarin kan navolg nie (vgl. Floor, 1998:105; Pelser, 1971:244). Omdat daar egter wel in die konteks van die himne oor selfvernedering gespreek word, verklaar sommige eksegete soos Hurtado (1984:119) en Kühl (1898:547) dat die oorspronklike lied 'n ander soteriologie aangebied het, maar dat dit deur 'n Pauliniese een vervang is. Volgens Käsemann (1960:79) was die himne oorspronklik eties van aard, maar Paulus (of watter skrywer ook al) het die lied soteriologies ingekleur. Hy sou dit gedoen het deur middel van die kenosis-leer (vs. 7) - vandaar die

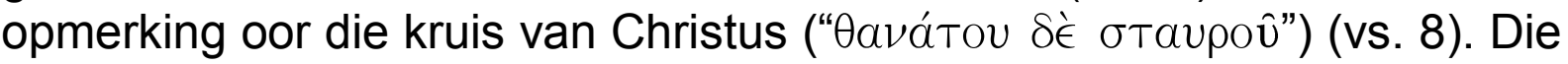
Christologie in sy huidige vorm van die lied sou daarom deur die apostel ingebou wees.

Marshall (1968:122) het oortuigend aangetoon dat die begrippe van vernedering en verhoging soos dit in die lied na vore kom, in die vroeë Christelike kerk wyd bekend was. In die Nuwe Testament kom hierdie begrippe op talle plekke voor (Joh. 3:13; 6:62; Rom. 1:3-4; Kol. 1:15-20; Heb. 2:9).

Ander eksegete (bv. Fee, 1995:197; Vögtle, 1963:205) wat die kenosisleer in die lied wel as oorspronklik beskou, lê soveel klem op die soteriologiese dat hulle die etiese aard van die lied misken. Maar dan word, soos reeds aangetoon, die lied uit sy konteks gehaal.

Indien 'n Pauliniese interpolasie in die oorspronklike lied aanvaar word, is die etiese aard van die lied moontlik, maar dan het hierdie himne geen soteriologiese basis nie. Wanneer daar egter aanvaar word dat die 
opmerking oor die kruis van Christus 'n deel is van die oorspronklike lied, bly die vraag hoe die etiese implikasies van die himne verklaar kan word.

Martin (1983:135) sien die oplossing daarin dat Paulus 'n himne oorgeneem het wat alleenstaande ' $n$ ander betekenis sou hê as wanneer dit in die konteks van Filippense gelees word. Buite die Filippensebrief sou dit dien as reaksie teen gnostiese leerstellings en om gelowiges in verdrukking te verseker dat die Here lewe en dat Hy die lotgevalle van die wêreld in sy hande hou. Paulus neem egter hierdie lied in sy brief op en dan kry die lied 'n ander betekenis. Binne die breë konteks van die brief waarsku hy sy lesers dat wanneer hulle onder die heerskappy van Christus leef, hulle lyding sal ervaar. Binne die enger konteks van 1:272:18 sou die lied hulle aanspoor om tot die dood toe aan Christus gehoorsaam te wees.

Die soteriologiese en etiese verklarings van die himne hoef mekaar egter nie uit te sluit nie. Indien die ontlediging van Christus in 'n etiese perspektief geplaas word (soos vervolgens aangetoon word), word dit duidelik dat hierdie himne (as die belangrikste gedeelte van die brief) sowel soteriologies as eties van aard kan wees.

\section{8. 'n Etiese perspektief op die kenosis}

Daar is teoloë (bv. Lindijer,1992:93) wat juis die ontlediging van Christus as voorbeeld tot navolging gebruik. In die hedendaagse sielsorg wat fokus op kommunikasie word die term ontlediging gebruik. So 'n oplossing vir die probleem is egter nie verantwoordbaar nie. Daar moet in gedagte gehou word dat die term ontlediging in die Nuwe Testament eksklusief betrekking het op Jesus Christus. Die ontlediging is ' $n$ Christologiese kategorie en nie 'n etiese een nie.

Daar is in die Christologie van die lied ook twee ander uitdrukkings wat ons in aanmerking kan neem vir die oplossing van die probleem. Jesus

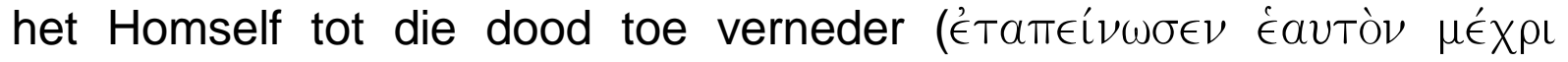
Өavátov) en Hy het gehoorsaam geword tot die die dood van die kruis

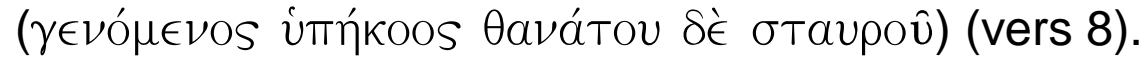

Daar moet 'n onderskeid gemaak word tussen sy vernedering en gehoorsaamheid aan die een kant, en sy ontlediging (die kenosis). Dit is nie dieselfde nie. Christus se vernedering en gehoorsaamheid moet gesien word as die gevolg van sy ontlediging. Hier het die apostel die punt bereik waar hy sy lesers wil bring. Die oproep tot ootmoed en nederigheid in vers 3 word hier gemotiveer. Christus as hoogste en volmaakte voorbeeld van nederigheid word aan die lesers tot navolging voorgehou. 
Daar is dus volgens hierdie lied in die optrede van Christus iets wat so uniek is dat dit nie kan en ook nie hoef nagevolg te word nie (om aan te sluit by Lohmeyer, 1928:75 en Martin, 1983:132). Maar tog is daar in Christus se optrede ook iets wat wel kan en moet nagevolg word. Die vraag is daarom waarin Christus nagevolg moet word. Dan is die antwoord nie in sy ontlediging nie, maar in sy gehoorsaamheid. Dit is opmerklik dat die skrywer van die brief in 2:12 aansluit by die gehoorsaamheid van Christus. Hy skrywe: "My geliefdes, julle was altyd

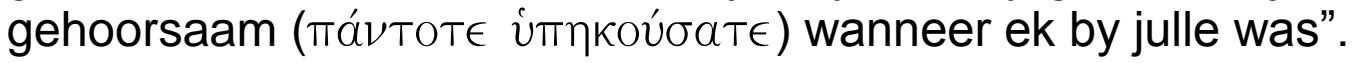

Navorsers verskil oor die vraag oor die regte verbinding met dit wat 2:12 voorafgaan. Dit kan wees met die vermaninge in 2:1-4 (Gnilka, 1968:156; Klijn, 1969: 93), 2:8 (Laurin, 1987:96), 2:6-11 (Lohmeyer, 1928:64) of selfs 1:27-2:11 (Greijdanus, 1937:208).

Wat ook al die presiese skakeling is, dit is wel duidelik dat die apostel 'n skakel lê tussen die gehoorsaamheid van Christus en dié van die gelowiges. Die weg van ootmoed, nederigheid en gehoorsaamheid word aan die lesers in Filippi voorgehou as ' $n$ weg in die voetstappe van Jesus.

Die etiek is in die soteriologie gefundeer. Nie in sy ontlediging nie, maar in sy nederige gehoorsaamheid moet Christus nagevolg word. Christus is in hierdie lied nie alleen maar die groot voorbeeld nie. Hy is tegelyk die waarborg dat ons bereidheid tot nederigheid en gehoorsaamheid ons verseker van God se heilstoesegging. Die navolging van Christus is nie 'n moraliserende opdrag nie. Die krag tot geloofsgehoorsaamheid lê in die geloof in die vernederde en verhoogde Christus.

Ook elders in sy briewe verbind die apostel die etiek met die dogmatiek, die etiese met die soteriologiese (vgl. Rom. 6:4). Hy doen dit in die wete dat ons alleen deur geloofsverbondenheid met die gekruisigde Christus die krag kan ontvang om in sy voetstappe te volg.

Die apostel Petrus koppel ook die etiese aan die soteriologiese wanneer hy skryf: "Omdat Christus vir julle gely het en so vir julle 'n voorbeeld gestel het, sodat julle in sy voetstappe kan volg" (1 Pet. 2:2).

Soos reeds aangetoon, vind ons op ander plekke in die Nuwe Testament verskillende aanwysings dat Jesus die groot voorbeeld is wat deur die gelowiges nagevolg moet word.

Ons leer uit hierdie Christus-himne dat die credenda en die legenda, die dogmatiek en die etiek onlosmaaklik aan mekaar verbind is en dat die soteriologiese en die etiese interpretasiemoontlikhede van die lied mekaar nie uitsluit nie. 


\section{Samevatting}

Samevattend kan ons sê dat in Paulus se brief aan die Filippense 'n doksologiese indikatief met 'n parenetiese imperatief verbind word. Geloof in die indikatief gee krag om die imperatief te gehoorsaam.

Die weg van ootmoed, nederigheid en gehoorsaamheid word aan die kerk ter navolging voorgehou. Die weg wat Jesus gegaan het en wat in die Christus-himne van 'n stap-vir-stap-selfprysgawe geteken word, is 'n teken van hoop vir die mensheid.

Die etiese en soteriologiese verklarings van die himne hoef daarom nie in konflik met mekaar te staan nie. Trouens, albei die verklarings moet verdiskonteer word om die betekenis en funksie van die himne te verstaan.

Baie mense dink dat selfverloëning en ootmoed jou nêrens bring nie. Die groot voorbeeld van Christus wys egter dat dit 'n nuwe perspektief open. Sowel vir Jesus (sy verhoging) as vir hulle wat in sy voetstappe volg, is hierdie weg nie 'n doodlooppad nie, maar 'n weg vol hoop en verwagting.

Hieroor moet die kerk van die Here sing!

\section{Bibliografie}

BARNIKOL, E. 1932. Der marcionitische Ursprung des Mythos-Satzes: Phil. 2,6-7: Prolegomena zur neutestamentlichen Dogmengeschichte. (Forschungen zur Entstehung des Urchristentums, des Neuen Testaments und der Kirche 7.) Kiel : Aschendorff.

BONNARD, P. 1950. L'Épître de Saint Paul aux Philippiens (Commentaire du Nouveau Testament X). Neuchatel-Paris : Delachaux.

BORNHÄUSER, K. 1938. Jesus Imperator Mundi (Phil. 23,17-21 und 2,5-11). Gütersloh : Mohr.

CERVAUX, L. 1946. L'hymne au Christ-Serviteur de Dieu (Phil. 2:6-11). Louvain : Bibliotheque de l'Université.

CULLMANN, O. 1957. Die Christologie des Neuen Testaments. Tübingen : Van Hoeck \& Ruprecht.

DIBELIUS, M. 1925. An die Thessalonicher I-II, An die Philipper. Tübingen : Mohr.

DUNN, J.D.G. 1980. Christology in the making. London : SCM.

FEE, G.D., 1995. Paul's letter to the Philippians. (The New Testament Commentary on the New Testament.) Grand Rapids : Eerdmans.

FITZMYER, J.A. 1968. Philippians. Englewood Cliffs : Sheffield.

FITZMYER, J.A. 1993. The Christological hymn of Philippians 2:6-11. (In Layman, L.M., ed. According to Paul. Studies in the theology of the Apostle Paul. New York : Abingdon. p. 89-105.)

FLOOR, L. 1998. Philippenzen. Een gevangene over de navolging van Christus (CNT). Kampen : Kok.

FURNESS, J.M. 1958. The authorship of Philippians 2:6-11. Expository Times, 70:240-243. 
GEORGI, D. 1964. Die vorpaulinische Hymnos Phil. 2,6-11. (In Dinkler, E., ed. Zeit und Geschichte. Dankesgabe an R. Bultmann zum 80. Geburtstag. Tübingen : Van Hoeck \& Ruprecht. p. 263-293.)

GNILKA, J. 1968. Der Philipperbrief. (Herders theologischer Kommentar zum Neuen Testament.) Freiburg : Herder.

GORE, J. 1891. The incarnation of the Son of God. (Bampton Lectures.) London : Collins.

GREIJDANUS, S. 1937. De brief van den apostel Paulus aan de Filippenzen. Amsterdam : Bottenburg.

GUNDRI, R.H. 1994. Style and substance. The myth of God Incarnate according to Philippians 2:6-11. (In Porter S.E., ed. Crossing the boundaries. Essays in Biblical interpretation in honour of Michael Goulder. (Biblical Interpretation Series 8.) Leiden : Brill. p. 271-293.)

GUTHRIE, D. 1970: New Testament Introduction. Leicester : Inter-Varsity.

HENDRIKSEN, W. 1962. New Testament Commentary; exposition of Philippians. Grand Rapids : Banner of Truth.

HUNZINGER, C-H. 1970. Zur Struktur des Christus-Hymnos in Phil. 2 und 1 Petr. 3. (In Lohse, E., ed. Der Ruf Jesu und die Antwort der Gemeinde. Festschrift für Joachim Jeremias. Göttingen : Vandenhoeck. p. 142-156.)

HURTADO, L.W. 1984. Jesus as Lordly example in Philippians 2:5-11. (In Richardson, P. \& Hurd, C., eds. From Jesus to Paul: Studies in honour of Francis Wright Beare. Waterloo : Wilfred Laurier University Press. p. 113-126.)

JEREMIAS, J. 1954. Pais Theou. (In Kittel, G., ed. Theologisches Wörterbuch zum Neuen Testament. Band V. Stuttgart : Kohlhammer. p. 676-713.)

JONES, M. 1918. Philippians. London : Duckworth.

KÄSEMANN, E. 1960. Kritische Analyse von Phil. 2,5-11. (Exegetische Versuche und Besinnungen.1:51-95.) Göttingen : VandenHoeck \& Ruprecht.

KENNEDY, G. 1984. New Testament interpretation through rhetorical criticism. Chapel Hill : Harper.

KLIJN, A.F.J. 1969. De brief van Paulus aan de Filippensen. (De prediking van het Nieuwe Testament.) Nijkerk : Callenbach.

KÜHL, E. 1898. Über Philipper 2:12,13. Theologischer Studien und Kritiken, 71:557581.

LAURIN, R.L. 1987. Philippians: Where life advances. Grand Rapids : Eerdmans.

LINDIJER, C.H. 1992. Jezus ter sprake. Op zoek naar de plaats van Jezus Christus in pastorale praktijk en pastorale psychologie. Zoetermeer : Boekencentrum.

LOHMEYER, E. 1928. Kyrios Jesus: Eine Untersuchung zu Phil. 2,5-11. Heidelberg : Meyer.

LOHMEYER, E. 1930. Die Briefe and die Philipper, Kolosser und an Philemon. (Kommentar NT Meyer.) Göttingen : Meyer.

MARSHALL, I.H. 1968. The Christ Hymn in Philippians 2:5-11. Tyndale Bulletin, 19:104-127.

MARTIN, R.P. 1967. Carmen Christi: Philippians 2:5-11 in recent interpretation and in the setting of early Christian worship. Cambridge : University Press.

MARTIN, R.P. 1983. New Testament hymns: Background and development. Expository Times, 94:132-136.

MOFFAT, J. 1918. An introduction to the literature of the New Testament. Edinburgh : Kingsway.

MURPHY-O'CONNOR, J. 1976. Christological anthropology in Phil. 2:6-11. Revue Biblique, 83:25-50. 
OEPKE, A. 1938. Kenos. (In Kittel, G., ed., Theologisches Wörterbuch zum Neuen Testament. Band III. Stuttgart : Kohlhammer. p. 659-662.)

PELSER, G.M.M. 1971. Die Carmen Christi Fil. 2:6-11. 'n Eksegeties-Christologiese ondersoek. Pretoria : Universiteit van Pretoria. (Doctor Divinitatis proefskrif.)

PLUMMER, A. 1919. A commentary on St. Paul's Epistle to the Philippians. Edinburgh : Clark.

ROBERTSON, A.T. 1917. Paul's joy in Christ. Grand Rapids : Baker Book House.

SANDERS, J.T. 1963. The comparative religious background of the New Testament Christological hymns. Michigan : Ann Arbor.

SCHENK, W. 1984. Die Philipperbrief des Paulus. Stuttgart : Klauser.

SNYMAN, A.H. 1989. Die Filippense-himne (Fil. 2:6-11). (In Barkhuizen, J.H., red. Hymni Christiani. Pretoria : Hervormde Teologiese Studies. p. 44-53.) (HTS Supplementum 1.)

STRECKER, G. 1964. Redaktion und Tradition in Christus-Hymnus Phil. 2,6-11. Zeitschrift für die neutestamentliche Wissenschaft, 55:63-78.

VILJOEN, F.P. 2001. Song and music in the Pauline epistles - Paul's utilisation of Jewish, Roman and Greek musical traditions to encourage the early Christian communities to praise God. In die Skriflig, 35(3):432-442.

VÖGTLE, A. 1963. Der Menschensohn und die paulinische Christologie. Analecta Biblica, 17-18:199-218.

WARREN, W. 1912. On 'heauton ekenoosen'. Journal of Theological Studies, 12: 461-463.

WEISS, J. 1897. Beitrage zur paulinischen Rhetorik. Göttingen : Vandenhoeck.

\section{Kernbegrippe:}

Christus-himne

etiese himne

Filippense 2:6-11

Filippense-himne

soteriologiese himne

\section{Key concepts:}

Christ hymn

ethical hymn

Philippians 2:6-11

Philippian hymn

soteriological hymn 